\title{
Elemental Concentrations of Aerosols in the City of Gaborone
}

\author{
K. Moloi, T.S.Verma \\ Department of Physics, University of Botswana, P/Bag UB 00704, Gaborone, Botswana \\ Corresponding author Email: vermat@mopipi.ub.bw
}

\begin{abstract}
This paper presents aerosol studies carried out in Gaborone, the capital city of Botswana. The Gaborone aerosol is varied consisting of elements from Si to Au. Traffic contribution to the aerosol of Botswana is clearly visible as illustrated by strong positive bromine and lead correlation. The use of unleaded petrol could be the cause of the decrease of ambient lead $(\mathrm{Pb})$ and bromine $(\mathrm{Br})$ concentrations when the present measurements are compared to previous measurements. The elements present in the aerosol of Gaborone range from silicon to lead.
\end{abstract}

Keywords - Particulate matter, Correlation, Regression, Ambient.

\section{INTRODUCTION}

The health effects of urban aerosols and particularly those derived from vehicles are the focus of attention in many countries. Particulate matter (PM) with aerodynamic diameter $\leq 10 \mu \mathrm{m}\left(\mathrm{PM}_{10}\right)$, especially the fine particle fraction of $\mathrm{PM}_{10}$, i.e. $\mathrm{PM}_{2.5}$ (particulate matter with aerodynamic diameter $\leq 2.5 \mu \mathrm{m}$ ) was found to associate with urban health problems such as increase in daily mortality (e.g. Dockery and Pope, 1994) and asthma (e.g. Anderson et al., 1992). This has been reflected in an increase in the amount of routine monitoring of atmospheric particles (Clarke et al., 1999).

Continues monitoring of airborne particulates is of great importance since a data base on concentration and its fluctuations at different representative sites of a given urban area is of particular relevance to any future planning towards the improvement and control of air quality.

In Botswana air pollution surveillance is carried out by the Department of waste management and pollution control pursuant to the Atmospheric Pollution (Prevention) Act of 1971 (Air Pollution Control, 1995). Most air pollution stations throughout the country are designed to measure sulphur dioxide $\left(\mathrm{SO}_{2}\right)$ and total suspended particulates. Thus, only a few aerosol characteristics have been measured so far. In some parts of Botswana one can notice the effects on vegetation due to emissions from mineral smelting industries. This could be a result of inefficient methods of production although the industries are few compared to those in industrialised countries.

Similar studies were conducted for about ten years at University of Botswana, Gaborone, where continuous monitoring of concentration of aerosols and polluting gases were carried out by using particle counters and gas analysers. The investigation from this studies have been described in several papers such as Jayaratne and Verma,2001; Verma and Thomas,2007; Verma and John,2009 and Verma et.al 2010.

This paper presents results of a study of urban aerosol particle composition the capital city of Botswana (Gaborone). This involved aerosol sampling with a dichotomous virtual impactor as well as sampling of black carbon and sulphur dioxide. The results have been compared to a previous study carried out in 1997 in the same city (Selin Lindgren et al., 1998).

\section{EXPERIMENTAL}

Sampling took place in the capital city of Botswana (Gaborone $\left(22.71^{\circ} \mathrm{S}, 25.9^{\circ} \mathrm{E}\right)$ ) with a population of 250000. The sampling site lies in a residential area located $\approx 500$ meters on the western side from the city centre. The measurement campaign extended from the $10^{\text {th }}$ to $30^{\text {th }}$ of August, 1999. The sampling duration was $12 \mathrm{hrs,} \mathrm{between}$ 8:00 am and 20:00 pm local time.

Aerosol particles were sampled with a dichotomous virtual impactor (Anderson model 245) operating at a total flow rate of $16.7 \mathrm{l} / \mathrm{min}$. In the impactor used in 1999 the cutpoint between coarse and fine particles was $2.5 \mu \mathrm{m}$ and the upper cut-off for coarse particles was $10 \mu \mathrm{m}$, while the lower and upper cut-off for the impactor used in the 1997 measurements were $3.5 \mu \mathrm{m}$ and $18 \mu \mathrm{m}$ respectively. Teflon membrane filters, manufactured by millipore (SA240PR100), were used. These filters have an aerial density of $0.9 \mathrm{mg} \mathrm{cm}^{-2}$, a diameter of $37 \mathrm{~mm}$ and a pore size of $2.0 \mu \mathrm{m}$. The filter material had been evaluated before 
sampling with regard to its blank values, and was shown to be very clean.

All impactor samples were analysed by multielement energy dispersive X-ray fluorescence (EDXRF) technique. The characteristic radiation from the sample is detected by a $\mathrm{Si}(\mathrm{Li})$ detector (active area $80 \mathrm{~mm}^{2}$, FWHM at $5.9 \mathrm{KeV}$ of $173 \mathrm{eV}$ ). The X-ray tube was operated at a voltage of $55 \mathrm{kV}$ and a current of $25 \mathrm{~mA}$. The live time of each spectrum was $1000 \mathrm{~s}$. For a detailed description of the spectrometer see papers by e.g. Standzenieks and Selin [1979] and Selin et al. [1991]. The detection limits for the spectrometer used are shown in Table 1.

Black carbon (BC) was sampled with a device consisting of a pump, a flow meter, a brass filter holder and a tube that ends with a funnel with the wide end facing downwards. The sampling rate was $16 \mathrm{l} / \mathrm{min}$. The filters used were of glass fibre material (GF 10) (Schleicher\&Schnell, ref.no 370393) in close agreement with the recommended type for the reflectometer (ESM Environmental Monitoring, 1998). The areal density of the filter is $6.7 \mathrm{mg} \mathrm{cm}^{-2}$. The filters were subsequently analysed with a light reflectance technique.

Sulphur dioxide was sampled with a self-contained high sensitivity pulsed fluorescence analyser Model 43S from Thermo Environmental Inc. operating at a flow rate of 0.5 1/min (Thermo Environmental Instruments Inc., 1996). Ten minutes averages were logged in a logger (Campbell CR10). The logger also recorded supporting weather variables like wind speed and direction. Table 2 presents a summary of the instruments used in this study.

Table.1: Detection limits for quantification of elements in airborne particles analysed with EDXRF technique from a

\begin{tabular}{|l|l|l|}
\multicolumn{3}{c}{ measurement using Teflon filters. } \\
\hline Element & $\begin{array}{l}\text { Detection limit }{ }^{\mathrm{a}} \\
\left(\mathrm{ng} / \mathrm{cm}^{2}\right)\end{array}$ & $\begin{array}{l}\text { Minimum airborne } \\
\text { concentration }^{\mathrm{b}}\left(\mathrm{ng} / \mathrm{m}^{3}\right)\end{array}$ \\
\hline $\mathrm{Si}$ & 1400 & 720 \\
\hline $\mathrm{S}$ & 90 & 46 \\
\hline $\mathrm{Cl}$ & 40 & 21 \\
\hline $\mathrm{K}$ & 15 & 7.7 \\
\hline $\mathrm{Ca}$ & 8.0 & 4.1 \\
\hline $\mathrm{Ti}$ & 5.1 & 2.6 \\
\hline $\mathrm{V}$ & 2.8 & 1.4 \\
\hline $\mathrm{Cr}$ & 2.1 & 1.1 \\
\hline
\end{tabular}

$\underline{\text { ww.ijjeab.com }}$

\begin{tabular}{|l|l|l|}
\hline $\mathrm{Mn}$ & 2.5 & 1.3 \\
\hline $\mathrm{Fe}$ & 1.3 & 0.67 \\
\hline $\mathrm{Ni}$ & 1.2 & 0.62 \\
\hline $\mathrm{Cu}$ & 0.95 & 0.49 \\
\hline $\mathrm{Zn}$ & 0.89 & 0.46 \\
\hline $\mathrm{Br}$ & 0.62 & 0.32 \\
\hline $\mathrm{Rb}$ & 0.54 & 0.28 \\
\hline $\mathrm{Sr}$ & 0.63 & 0.32 \\
\hline $\mathrm{Pb}$ & 0.92 & 0.47 \\
\hline
\end{tabular}

${ }^{a}$ Detection limits are calculated using the three times square root of background $(3 \sigma)$. The time of spectrum acquisition considered is $1000 \mathrm{~s}$.

${ }^{b}$ The minimum airborne elemental concentrations are calculated with respect to the 12 hours sampling time used in this study.

Table.2: Instruments used to measure atmospheric variables in the present work.

\begin{tabular}{|l|l|}
\hline INSTRUMENT & MODEL \\
\hline Dichotomous Impactor & Anderson \\
\hline $\mathrm{SO}_{2}$ Analyser & $\begin{array}{l}\text { Model 43S from Thermo } \\
\text { Environmental Inc. }\end{array}$ \\
\hline Logger and & Campbell CR 10 \\
\hline $\begin{array}{l}\text { Wind Speed monitor-AQ } \\
\text { direction }\end{array}$ & $\begin{array}{l}\text { Laboratory modified } \\
\text { with a brass holder }\end{array}$ \\
\hline Black Carbon sampler \\
\hline
\end{tabular}

\section{RESULTS AND DISCUSSION}

\subsection{Element concentrations}

The levels of measured elemental concentrations in the urban aerosols of Gaborone are presented in Table 3 for the fine and coarse particle fractions, respectively. The data from a previous measurement by Selin Lindgren et. al. (1998) are presented for comparison.

As can be noted from Table 3 the values from the 1999 measurements are of the same order of magnitude as those from 1997. The soil derived elements from the Gaborone 1999 measurements are slightly higher that the ones from Gaborone 1997. This could be explained by the fact that the measurements in 1999 were taken at 1.5 meters above ground level while the 1997 measurements were taken on a rooftop 15 meters above ground level. It may be noted that the $\mathrm{Pb}$ and $\mathrm{Br}$ levels for Gaborone 1999 are lower than

Page $\mid 702$ 
those of 1997. There has been a shift in Botswana since 1997, from using leaded to unleaded gasoline, which can explain the decrease in the $\mathrm{Pb}$ and $\mathrm{Br}$ levels. Secondly the Gaborone 1997 site is closer to the university car parking lot which can also have an influence on the $\mathrm{Pb}$ and $\mathrm{Br}$ levels. The observation of decreasing $\mathrm{Pb}$ and $\mathrm{Br}$ levels demonstrates that the increasing use of unleaded petrol during the last years, is leading, as desired, to diminished lead ambient concentrations. Note, that the sum of coarse and fine $\mathrm{Pb}$ and $\mathrm{Br}$ for Gaborone 1999 is still smaller than the fine particle fraction alone for Gaborone 1997, and hence the decreasing concentrations can not be attributable to the difference in impactor cut-offs.

The concentration of Lead, one of the pollutants present in the atmosphere, with many related health effects is investigated. The investigation is to determine the effects of the implemented restriction on usage of leaded petrol in Botswana(Botswana Govt. 1 April 2006).The monitoring of lead present in environment of Gaborone was conducted , and it was found over a period of two months the concentration declined in 84 days was seen to be about $24 \%$ (Verma et al 2010)

It is thought that this effect is due to the transition of the usage of unleaded petrol in Botswana which began from 1 April 2006. We should bear in mind that the lead particle emitted from the leaded petrol before the transition date could remain in the atmosphere for several months. The measurements (Hana et al., 1983) show that $25 \%$ of the vehicular emission, lead, is in the form of large, coarse particles which settle on the road-side and the rest are of a fine size which remain floating for a considerable time due to their high residence.

It is interesting to note that the concentrations of $\mathrm{SO}_{2}$ and BC in Gaborone 1999 compares to those of cities in industrialised countries. $\mathrm{Cu}$ and $\mathrm{Ni}$ concentrations are low in Gaborone when compared to other places where $\mathrm{Cu}$ and Ni are mined (Chimidza and Moloi, 2000).

Table.3: Means, medians and Interquartile ranges (IQR) for this study (Gab99) and a previous study carried out in 1997 (Gab97).

Elements in both fine $(f)$ and coarse (c) particles are presented along with $\mathrm{BC}$ and $\mathrm{SO}_{2}$. Units are $\mathrm{ng} \mathrm{m}^{-3}$ for the element concentrations and $\mu \mathrm{g} \mathrm{m}^{-3}$ for $\mathrm{BC}$ and $\mathrm{SO}_{2}$.

\begin{tabular}{lllllll}
\multicolumn{7}{c}{ concentrations and $\mu \mathrm{m}^{-3}$ for BC and $\mathrm{SO}_{2}$. } \\
\hline Element & \multicolumn{7}{c}{ Gab99 } & & Gab97 & $\begin{array}{c}\text { Vemadata } \\
(2009)\end{array}$ \\
\cline { 2 - 7 } & Mean & Median & IQR & Mean & Median & IQR \\
\hline $\mathrm{Si}(\mathrm{c})$ & 6700 & 7000 & 2100 & 4400 & 4600 & 1800 \\
$\mathrm{Si}(\mathrm{f})$ & 720 & 630 & 720 & $\mathrm{BDL}$ & $\mathrm{BDL}$ & $\mathrm{BDL}$ \\
$\mathrm{S}(\mathrm{f})$ & 1400 & 1200 & 750 & 1200 & 1100 & 340 \\
$\mathrm{Cl}(\mathrm{c})$ & 200 & 190 & 110 & 110 & 87 & 120 \\
$\mathrm{Cl}(\mathrm{f})$ & $\mathrm{BDL}$ & $\mathrm{BDL}$ & $\mathrm{BDL}$ & 100 & 45 & 89 \\
$\mathrm{~K}(\mathrm{c})$ & 1100 & 1100 & 370 & 590 & 560 & 170 \\
$\mathrm{~K}(\mathrm{f})$ & 310 & 300 & 86 & 650 & 630 & 210 \\
$\mathrm{Ca}(\mathrm{c})$ & 900 & 940 & 350 & 760 & 780 & 430 \\
$\mathrm{Ca}(\mathrm{f})$ & 100 & 99 & 50 & 160 & 130 & 110 \\
$\mathrm{Ti}(\mathrm{c})$ & 280 & 280 & 110 & 190 & 190 & 76 \\
$\mathrm{Ti}(\mathrm{f})$ & 34 & 32 & 21 & 41 & 39 & 34 \\
$\mathrm{Cr}(\mathrm{c})$ & 6.1 & 4.8 & 3.0 & $\mathrm{BDL}$ & $\mathrm{BDL}$ & $\mathrm{BDL}$ \\
$\mathrm{Cr}(\mathrm{f})$ & 1.2 & 0.9 & 1.0 & $\mathrm{BDL}$ & $\mathrm{BDL}$ & $\mathrm{BDL}$ \\
$\mathrm{Mn}(\mathrm{c})$ & 52 & 50 & 20 & 53 & 51 & 19 \\
$\mathrm{Mn}(\mathrm{f})$ & 7.8 & 7.1 & 3.4 & 14 & 13 & 13 \\
$\mathrm{Fe}(\mathrm{c})$ & 2600 & 2600 & 970 & 2400 & 2300 & 960 \\
$\mathrm{Fe}(\mathrm{f})$ & 350 & 320 & 210 & 600 & 460 & 540 \\
$\mathrm{Ni}(\mathrm{c})$ & 2.5 & 2.7 & 1.0 & $\mathrm{BDL}$ & $\mathrm{BDL}$ & $\mathrm{BDL}$ \\
$\mathrm{Ni}(\mathrm{f})$ & 0.7 & 0.6 & 0.3 & $\mathrm{BDL}$ & $\mathrm{BDL}$ & $\mathrm{BDL}$ \\
$\mathrm{Cu}(\mathrm{c})$ & 6.4 & 6.5 & 3.2 & 10 & 8.0 & 6.0 \\
$\mathrm{Cu}(\mathrm{f})$ & 2.1 & 1.7 & 1.4 & 7.0 & 6.0 & 5.0 \\
$\mathrm{Zn}(\mathrm{c})$ & 14 & 12 & 7.0 & 21 & 19 & 13 \\
& & & & & &
\end{tabular}

www.ijeab.com 


\begin{tabular}{lllllll}
$\mathrm{Zn}(\mathrm{f})$ & 6.2 & 5.4 & 4.0 & 28 & 22 & 18 \\
$\mathrm{Br}(\mathrm{c})$ & 11 & 11 & 7.1 & 15 & 16 & 15 \\
$\mathrm{Br}(\mathrm{f})$ & 55 & 54 & 38 & 120 & 100 & 130 \\
$\mathrm{Rb}(\mathrm{c})$ & 10 & 11 & 4.6 & 12 & 11 & 4.0 \\
$\mathrm{Rb}(\mathrm{f})$ & 1.4 & 1.1 & 0.9 & 3.0 & 3.0 & 4.0 \\
$\mathrm{Sr}(\mathrm{c})$ & 4.1 & 4.3 & 1.8 & 6.0 & 6.0 & 2.0 \\
$\mathrm{Sr}(\mathrm{f})$ & 0.4 & 0.3 & 0.3 & 2.0 & 1.0 & 2.0 \\
$\mathrm{~Pb}(\mathrm{c})$ & 20 & 20 & 12 & 38 & 39 & 33 \\
$\mathrm{~Pb}(\mathrm{f})$ & 79 & 79 & 64 & 230 & 210 & 250 \\
$\mathrm{BC}$ & 1.3 & 1.3 & 0.3 & $\mathrm{~nm}$ & $\mathrm{~nm}$ & $\mathrm{~nm}$ \\
$\mathrm{SO}_{2}$ & 54 & 55 & 27 & $\mathrm{~nm}$ & $\mathrm{~nm}$ & $\mathrm{~nm}$ \\
\hline
\end{tabular}

BDL: data was below detection limit.

nm: data was not measured.

Gab99:Gaborone 1999 measurements, Gab97: Gaborone 1997 measurements.

For Gab99 fine particles (f), $\mathrm{d}_{\mathrm{a}}<2.5 \mu \mathrm{m}$ and coarse particles (c), $2.5 \mu \mathrm{m}<\mathrm{d}_{\mathrm{a}}<10 \mu \mathrm{m}$

For Gab97 fine particles (f), $\mathrm{d}_{\mathrm{a}}<3.5 \mu \mathrm{m}$ and coarse particles (c), $3.5 \mu \mathrm{m}<\mathrm{d}_{\mathrm{a}}<18 \mu \mathrm{m}$

3.2. Elemental ratios of some fine particle elements

Fig. 1 represents the regression line of fine particle $\mathrm{Br}$ against fine particle $\mathrm{Pb}$ in Gaborone aerosols. As can be noted there is a strong correlation $\left(\mathrm{R}^{2}=0.99\right)$. This could indicate internally mixed $\mathrm{Pb}$ and $\mathrm{Br}$ originating from the same source (automobile exhausts). The corresponding slope of the regression line is 0.7 and thus is higher than the ratio of 0.45 obtained in the 1997 measurements ('Shell South Africa' personal communication). An explanation could be that the petrol additive used in Gaborone 1999 has a different $\mathrm{Br}-\mathrm{Pb}$ ratio from the one used in Gaborone 1997.

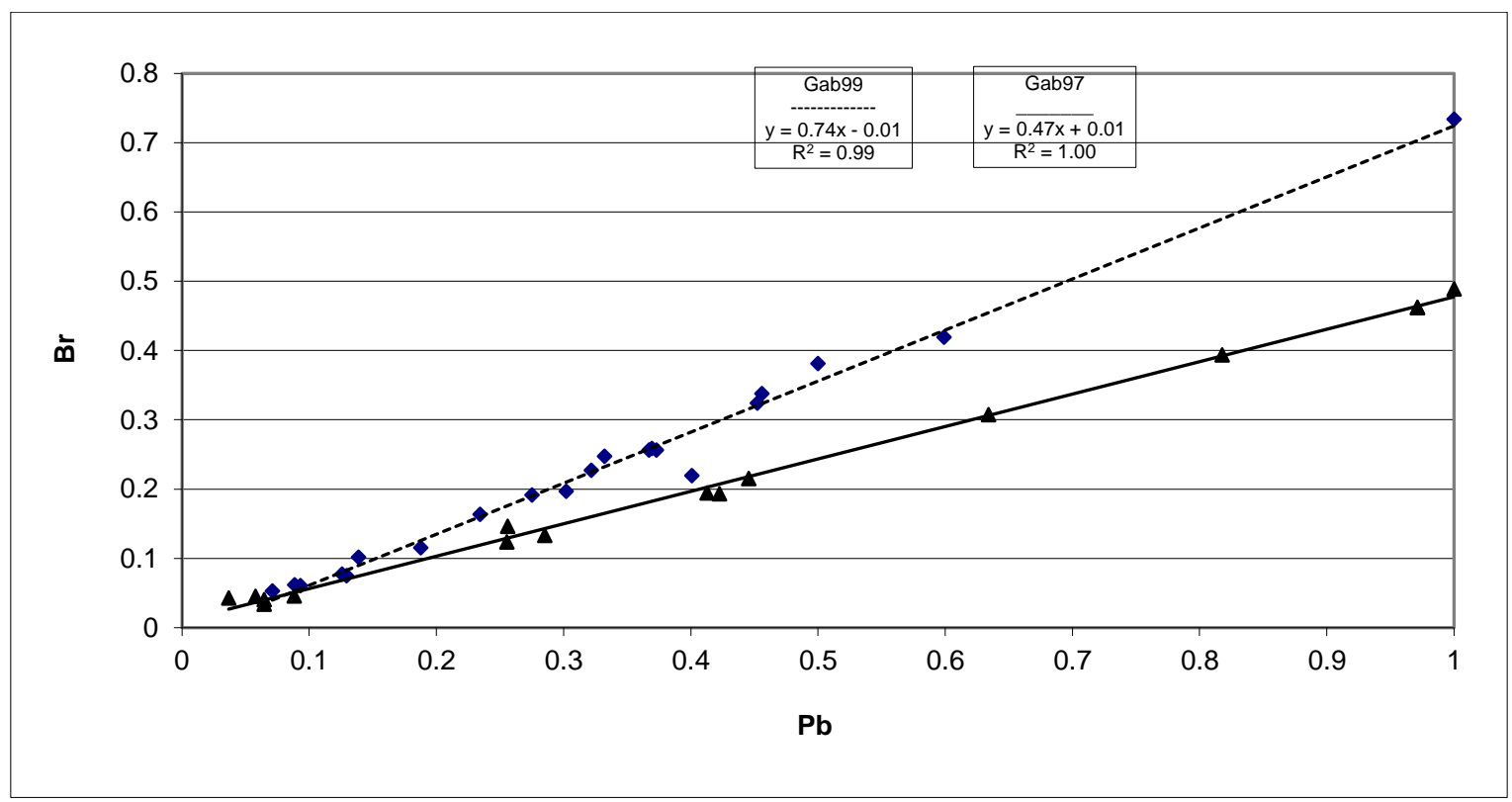

Fig.1: Regression line of normalised fine particle Br against normalised fine particle Pb for Gaborone 1999 and Gaborone 1997. The plotted values for both Br and Pb are normalised to the maximum value of Pb in both cases. (For Gaborone 1997, $[\mathrm{Br}]_{\max }=290 \mathrm{ng} / \mathrm{m}^{3},[\mathrm{~Pb}]_{\max }=600 \mathrm{ng} / \mathrm{m}^{3} ;$ For Gaborone 1999, $\left.[\mathrm{Br}]_{\max }=180 \mathrm{ng} / \mathrm{m}^{3},[\mathrm{~Pb}]_{\max }=240 \mathrm{ng} / \mathrm{m}^{3}\right)$. 


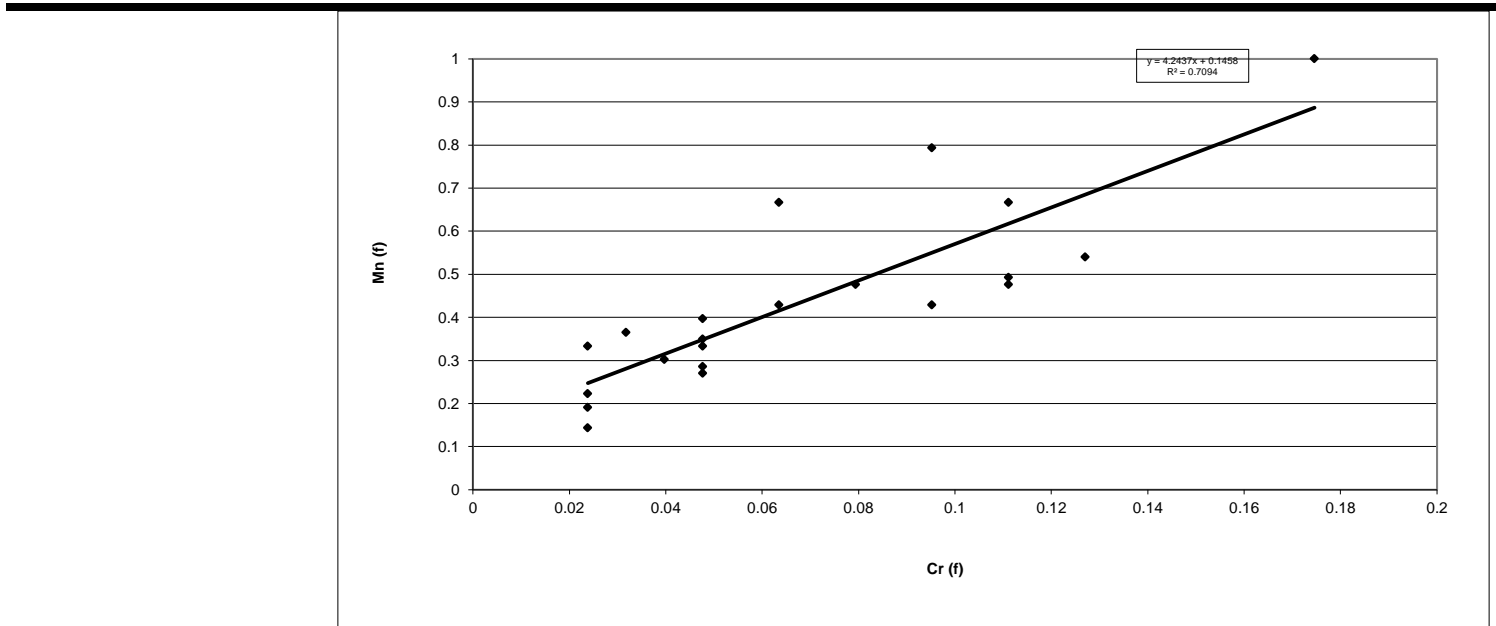

Fig.2: Regression line of normalised fine particle Mn versus normalised fine particle Cr for Gaborone 1999. The values are normalised to the maximum value of $\mathrm{Mn} .\left([\mathrm{Mn}]_{\max }=17 \mathrm{ng} / \mathrm{m}^{3},[\mathrm{Cr}]_{\max }=3.1 \mathrm{ng} / \mathrm{m}^{3}\right)$

Many of the anthropogenic fine particle elements have positive correlation. As an example Fig. 2 illustrates that the two elements $\mathrm{Mn}$ and $\mathrm{Cr}$ could have a common source or come from the same source region. The two elements Mn and $\mathrm{Cr}$ are very harmful to the environment and they have been found to be enhanced near an oil refinery (Mikula, 1997). Both are also effluent elements in the manufacture of stainless steel. Some $\mathrm{Cr}$ compounds are known to be carcinogenic to humans (Edme et al., 1997).

The study conducted at University of Botswana ( Verma and John 2009) has also investigated elemental analysis of the elements present in the environment of Gaborone. Their findings revealed that elements detected in the atmospheric particles of Gaborone were $\mathrm{Al}, \mathrm{Si}, \mathrm{Fe}, \mathrm{K}, \mathrm{Ca}, \mathrm{Mg}, \mathrm{Zn}, \mathrm{Na}$, $\mathrm{Cu}, \mathrm{Pb}, \mathrm{Ti}, \mathrm{Ni}, \mathrm{Pt}, \mathrm{Au}$ and $\mathrm{Cr}$. The frequently occurring elements were silicon, aluminium, iron, copper and lead. The most frequently occurring element was silicon and least frequently occurring element was platinum. The major percentage of elements present in the atmosphere of Gaborone was nickel, copper, lead and gold.

\section{CONCLUSION}

Comparison of results from Gaborone 1999 and Gaborone 1997 indicates that lead concentrations have significantly decreased during the last years. This demonstrates that the increasing use of unleaded petrol during the last years, is leading, as desired, to diminished $\mathrm{Pb}$ ambient concentrations.

Regression analysis has pointed to a few sources, which contribute to the Gaborone aerosol. The results indicate relatively high levels of local air pollution originating from both the natural and anthropogenic sources. As an example it can be mentioned that $\mathrm{Pb}$ and $\mathrm{Br}$ show a very high correlation coefficient indicating that they come from the same source which in this case is traffic.

The Gaborone aerosol consists of a wide range of aerosols both natural and anthropogenic. It varies from silicon to lead.

Although Botswana is a developing country some localised aerosol concentration like $\mathrm{SO}_{2}$ and $\mathrm{BC}$ compared to those of industrialised countries.

The results from this study compared with similar studies done by Verma et. al.(2009) and(2010)., It is desirable that measurements with longer sampling times be undertaken in the future in order to further elucidate some of the observed phenomena. Longer time sampling measurements will give results with more statistical significance.

\section{REFERENCES}

[1] Air Pollution Control. 1995. Annual report. Department of Mines, Printed by the Government Printer, Gaborone, Botswana.

[2] Anderson, K.R., Avol, E.L., Edwards, S.A., Shamoo, D.A., Peng, R.C., Linn, W.S., Hackney, J.D., 1992. Controlled exposures of volunteers to respirable carbon and sulfuric acid aerosols. Journal of Air and Waste Management Association 42, 770-776.

[3] Butcher, S.S., Charlson, R.J., Orians, G.H., Wolfe, G.V. 1992. Global Biogeochemical cycles, pp.226. Academic Press, London.

[4] Chow, T.J., 1970. Lead accumulation in roadside soil and grass. Nature 225, 295-296.

[5] Chimidza, S., Moloi, K., 2000. Identification of sources of aerosol particles in three locations in eastern Botswana, Journal of Geophysical research 105(D14), 17811-17818. 
[6] Clarke, A.G., Azadi-Boogar, G.A., Andrews, G.E., 1999. Particle size and chemical composition of urban aerosols. The Science of the Total Environment 235, $15-24$

[7] Dockery, D.W., Pope, C.A., 1994. Acute respiratory effects of particulate air pollution. Annual Reviews of Public Health 15, 107-132.

[8] Edme, J.L., Shirali, P., Mereau, M., Sobaszek, A., 1997. Assessment of biological chromium among stainless steel and mild steel welders in relation to welding processes. International Archives of Occupational Environmental Health 70, 237-242.

[9] ESM Environmental Monitoring, SB-008-980405E., 1998. Reflectometer for Particulate Monitor.

[10]Fergusson, J.E., 1986. Lead: Petrol lead in the environment and its contribution to human blood lead levels. The Science of the Total Environment 50, 1-54.

[11] Government of Botswana 2005. "Circular Ref. MW 6/11 VI (10)", Ministry of Minerals, Energy and Water affairs.

[12] Gulson, B.L., Tiller K.G., Mizon K.J., Merry R.H., 1981. Use of lead isotopes in soils to identify the source of lead contamination near Adelaide, South Australia. Environmental Science Technology 15. 691696.

[13] Hana, A. A. K., Al-Bassam, K. S., 1983. “A Survey of Lead Pollution in Bagdad", Water, Air and Soil Pollution, 19, 3-14.

[14]Harrison, R.M., Sturges, W.T., 1983. The measurement and interpretation of $\mathrm{Br} / \mathrm{Pb}$ ratios in airborne particles. Atmospheric environment 17(2), 311-328.

[15] Jayaratne E.R., Verma T.S., 2001. "The Impact of Biomass Burning on the Environmental Aerosol Concentration in Gaborone, Botswana", Atmospheric Environment 35, 1821-1828.

[16]Liu, X., Hopke, P.K., Cohen, D., Bailey, G., 1995. Sources of fine particle lead, bromine, and elemental carbon in south-eastern Australia. The Science of the Total Environment 175, 65-79.

[17] Mikula, W., Indeka, L., 1997. Heavy metals in allotment gardens close to an oil refinery in Plock. Water, Air and Soil Pollution 96, 61-71.

[18] Moloi, K., Chimidza, S., Viksna, A., Selin Lindgren, E. and Standzenieks P., 2000. Elemental profiles and light extinction of airborne black particles, Submitted to $X$-ray spectrometry.

[19] National Science Foundation NSF., 1999. Office of Legislative and Public affairs, http://www.nsf.gov/od/lpa/news/press/99/pr9940.htm.
[20] Selin, E., Oblad M., Standzenieks, P., Boman, J., 1991. Polarization effects in a $\mathrm{Si}(\mathrm{Li})$ Detector, $X$-ray Spectrometry 20, 325-330.

[21] Selin, L.E., Moloi, K., Stikans, M., Chimidza, S., 1998. Levels and Sources of Particle Air Pollution in Botswana studied by EDXRF Technique. in Proceedings of the European Conference on Energy Dispersive X-Ray Spectrometry 1998, pp. 269-273, Bononia University Press, Bologna.

[22] Shell South Africa., 1997. personal communication.

[23] Standzenieks, P., Selin, E., 1979. Background Reduction of X-ray Fluorescence Spectra in a Secondary Target Energy Dispersive Spectrometer, Nuclear Instruments and Methods 165, 63-65.

[24] Thermo Environmental Instruments Inc., 1996. Model 43S Trace level Pulsed Fluorescence $\mathrm{SO}_{2}$ Analyser Instruction Manual.

[25] Verma, T.S., Thomas, T.A., 2007. "Atmospheric Aerosol Concentration due to Biomass Burning", The International Journal of Meteorology, Vol. 32 No.321.

[26] Verma,T,S.,John,S.K.,2009." Elemental Analysis of Atmospheric Aerosols in Gaborone" African Journal of Environmental Science and Technology vol.3(12),pp422-428.

[27] Verma T S., Chimidza S. and Molefhi T., 2010. "Study of Indoor Air Pollution from Household Fuels in Gaborone, Botswana". Journal of African Earth Sciences, 58, p.648-65. 